Institute of $\mathbf{F}_{\text {ood and }} \mathbf{A}_{\text {gricultural }} \mathbf{S}_{\text {ciences }}$

\title{
Beelouse, Braula coeca Nitzsch (Insecta: Diptera: Braulidae) ${ }^{1}$
}

Howard V. Weems, Jr. and Malcolm T. Sanford ${ }^{2}$

\section{Introduction}

The beelouse, Braula coeca Nitzsch 1818, is a tiny commensalate wingless fly found in colonies of the honey bee, Apis mellifera Linnaeus, where it lives on the bodies of the bees and literally steals its food out of the mouth of its host. The beelouse is in the family Braulidae, comprising two genera, Braula and Megabraula, contains eight species (see Papp 1984f; Huttinger 1980; Grimaldi and Underwood 1986).

As many as 187 beelice have been reported on a single bee queen. The beelouse was first mentioned in European literature in 1740 by Reaumur, who discussed its relation to the honey bee. Skaife (1921) and Argo (1927) described fairly completely the life cycle of the insect, while Arnhart (1923) found the mines and dried out larval skins under honey cappings. The beelouse is found on worker, drone, and queen honey bees (Smith 1978). It probably was first introduced into the United States from Europe along with the first shipments of honey bees.
Some writers have stated that the beelouse causes little or no harm to bee colonies, but most investigators think that Braula is harmful. The larvae are problematic because they damage the appearance of comb honey by burrowing under the cappings.

Most beekeepers practice mechanical control unknowingly by extracting honey because the Braula larvae are eliminated while removing cappings before extraction. Chemical control measures have been developed in Europe and Asia, where the beelouse is much more common than in North America, but no pesticide has been registered for use against the beelouse in the United States. Because of the frequent movement of large numbers of bee colonies throughout much of the United Stated, there probably is little that can be done to prevent the spread of the beelouse, and its control may be accomplished through mechanical practices of the beekeepers. However, Florida beekeepers should be alert to the occurrence of this insect.

1. This document is EENY-171 (originally published as DPI Entomology Circular 252), one of the Featured Creatures series of the Entomology and Nematology Department, Cooperative Extension Service, Institute of Food and Agricultural Sciences, University of Florida. Published: November 2000. This document is also available on Featured Creatures Website at http://creatures.ifas.ufl.edu. Please visit the EDIS Website at http://edis.ifas.ufl.edu. Additional information on these organisms, including many color photographs, is available at the Entomology and Nematology Department website at http://entnemdept.ifas.ufl.edu/.

2. Howard V. Weems, Jr., Florida Department of Agriculture and Consumer Services, Division of Plant Industry and Malcolm T. Sanford, Entomology and Nematology Department, Florida Cooperative Extension Service, Institute of Food and Agricultural Sciences, University of Florida, Gainesville, FL.

The Institute of Food and Agricultural Sciences (IFAS) is an Equal Employment Opportunity - Affirmative Action Employer authorized to provide research, educational information and other services only to individuals and institutions that function without regard to race, creed, color, religion, age, disability, sex, sexual orientation, marital status, national origin, political opinions or affiliations. For information on obtaining other extension publications, contact your county Cooperative Extension Service office. Florida Cooperative Extension Service / Institute of Food and Agricultural Sciences / University of Florida / Larry R. Arrington, Interim Dean 


\section{Distribution}

This fly has been reported in Africa from Congo, Egypt, and Morocco, in Asia from India and the Soviet Union, in Australia from Tasmania, in most of Europe, in South America from Argentina, Brasil, Trinidad and Tobago, and Venezuela, and in North America from the United States: Alabama, Delaware, Illinois, Maryland, Minnesota, New York, North Carolina, Ohio, Pennsylvania, Tennessee, Virginia, West Virginia, and Wisconsin (Smith and Caron 1985). In Florida it is known only from a single specimen collected on a queen honey bee by DPI Apiary Inspector James Hall in Lake County near Umatilla on 17 March 1983.

\section{Identification}

\section{Eggs}

Eggs are white, oval-shaped, with two lateral flanges which are flat and extend parallel to each other and to the long axis of the egg. Imms (1942) reported that the average length, without flanges, ranged from 0.78 to $0.81 \mathrm{~mm}$ and the width from 0.28 to $0.33 \mathrm{~mm}$. Including the flanges, a typical egg measured $0.84 \mathrm{~mm}$ by $0.42 \mathrm{~mm}$. Eggs may be deposited in various places in a hive--in empty cells, on brood cell cappings, or on wax dirt on the floor of a colony, but only eggs that are laid on honey cappings hatch. Incubation period for eggs varies from two days during summer to 7.4 days during winter.

\section{Larvae}

Larvae emerge from the attached end of their egg where they begin constructing a tunnel under cappings and sometimes on the walls and bottoms of cells. These tunnels give cappings of infested comb the appearance of being intersected with fine fractures, similar to the mines of a leaf miner. Larvae feed upon honey and pollen grains within the wax of their tunnels. Beelouse larvae pass through three instars, requiring from 7.1 to 10.8 days to complete larval development, depending upon the season of the year.

\section{Pupa}

The prepupa ranges from 1 to 2.7 days and appears cream-white when viewed through the transparent larval skin. The pupa is enclosed within the unmodified cuticle of the last larval instar and is white or yellowish in color, 1.4 to $1.7 \mathrm{~mm}$ long by 0.5 to $0.75 \mathrm{~mm}$ wide.

\section{Adult}

The beelouse has eye rudiments just above the antennae seen as pale spots on the cuticle surface surrounded by more darkly pigmented chitinous rings. There is no trace of wings or halteres. The tarsi are 5-segmented; each terminal joint contains a comb-like structure, divided in the middle, with a variable number of teeth. The combs allow Braula to cling tightly to the host.

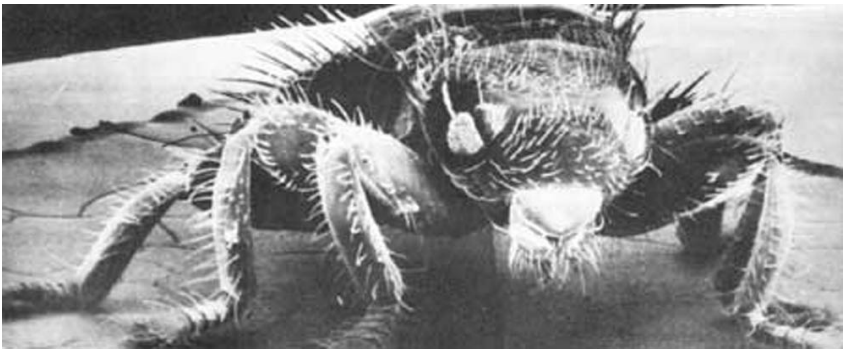

Figure 1. Frontal view of an adult beelouse, Braula coeca Nitzsch. Credits: W.J. Humphreys, University of Georgia

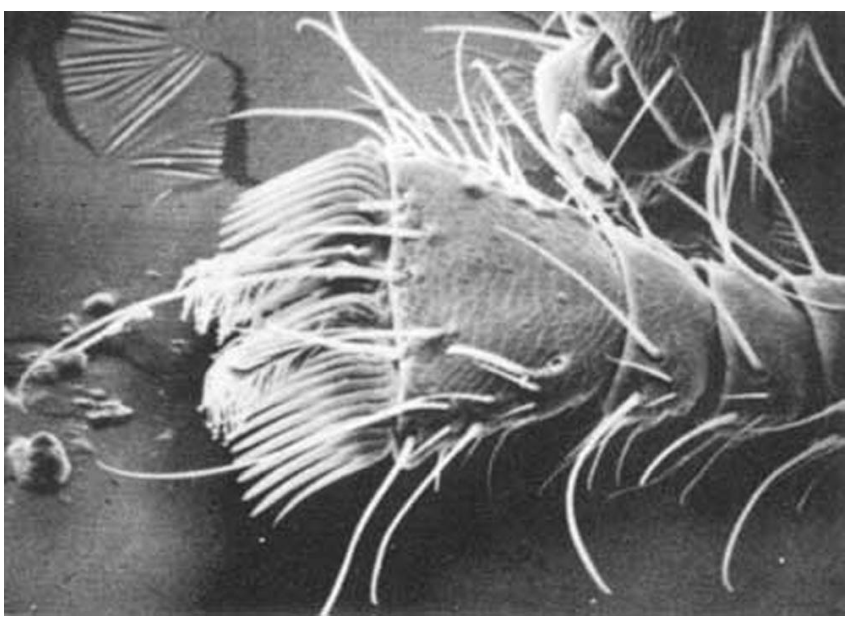

Figure 2. Dorsal view of a tarsus of an adult beelouse, Braula coeca Nitzsch, showing the comb-shaped row of spines, or claw, important in clinging to the branched hairs of the bee. Credits: W.J. Humphreys, University of Georgia 


\section{Survey and Detection}

Careful inspection of individual bees within the hive is the only effective method of collecting specimens of the tiny beelouse. Specimens may be preserved in $75 \%$ isopropyl alcohol.

\section{Selected References}

Argo, V.N. 1927. Braula coeca in den Vereinigten Staaten. Archiv für Bienenkunde 8: 48-52.

Arnhart, L. 1923. Zur Entwicklungsgeschichte der Braula coeca Nitzsch. Zool. Anz. 56: 193- 97.

Imms, A.D. 1942. On Braula coeca Nitzsch and its affinities. Parasit. 34: 88-100.

Nitzsch, C.L. 1818. Die Familien und Gattungen der Thierinsekten (Insecta epizoica); als prodromus einer naturgeschichte der selben. Magazin Ent. 3: 261-316.

Papp, L. 1984f. Family Braulidae, p. 178-80. In: Soós, Á. \& L. Papp, eds., Catalogue of Palaearctic Diptera. Volume 10. Clusiidae--Chloropidae. Akadémiai Kiadó, Budapest. 402 p.

Reaumur, R.A.F. de. 1740. Memoirs pour servir a l'histoire des insectes, 5. Paris.

Skaife, S.H. 1921. The life-history of the bee louse. S. African Bee. J. 1: 38-39.

Smith, I.B., Jr. 1978. The bee louse, Braula coeca Nitzsch, its distribution and biology on honey bees. Unpub. MS thesis, Univ. Maryland. 111 p.

Smith, I.B., Jr. \& D.M. Caron 1985. Distribution of the beelouse, Braula coeca, in Maryland and worldwide. Am. Bee J. 125: 294-96. 